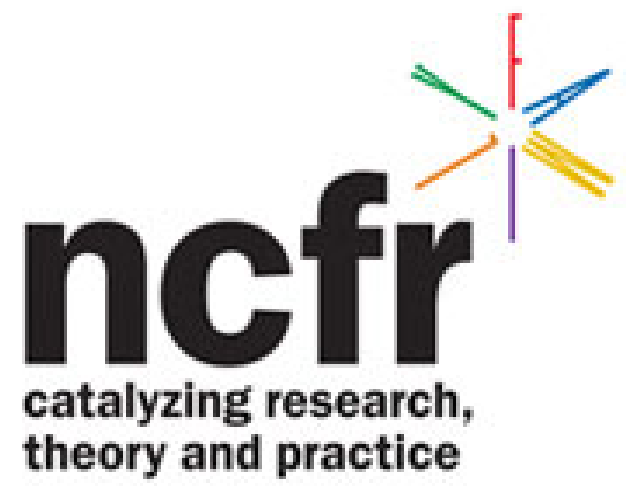

Changing Patterns of Remarriage

Author(s): Larry Bumpass, James Sweet, Teresa Castro Martin

Source: Journal of Marriage and Family, Vol. 52, No. 3 (Aug., 1990), pp. 747-756

Published by: National Council on Family Relations

Stable URL: http://www.jstor.org/stable/352939

Accessed: 03/09/2009 07:21

Your use of the JSTOR archive indicates your acceptance of JSTOR's Terms and Conditions of Use, available at http://www.jstor.org/page/info/about/policies/terms.jsp. JSTOR's Terms and Conditions of Use provides, in part, that unless you have obtained prior permission, you may not download an entire issue of a journal or multiple copies of articles, and you may use content in the JSTOR archive only for your personal, non-commercial use.

Please contact the publisher regarding any further use of this work. Publisher contact information may be obtained at http://www.jstor.org/action/showPublisher?publisherCode=ncfr.

Each copy of any part of a JSTOR transmission must contain the same copyright notice that appears on the screen or printed page of such transmission.

JSTOR is a not-for-profit organization founded in 1995 to build trusted digital archives for scholarship. We work with the scholarly community to preserve their work and the materials they rely upon, and to build a common research platform that promotes the discovery and use of these resources. For more information about JSTOR, please contact support@ jstor.org. 


\section{Changing Patterns of Remarriage}

Beginning with a brief review of recent trends in remarriage rates, this article focuses on the variation in these rates as measured in the 1980 and 1985 June Current Population Surveys. For reasons of data quality, the focus is on rates observed in the five years before each of these surveys. After a discussion of the demographic composition of separation cohorts as a factor affecting remarriage rates and ultimately the structure of remarriages, the article next examines proportional-hazard estimates of differentials in remarriage rates. Finally, using life-table procedures, the study draws out some of the important implications of differing remarriage rates by estimating expected proportions who will ever remarry.

Recent trends in divorce and remarriage have created great diversity in the family life course. Only a third of recent first marriages are likely to stay together until widowhood (Castro Martin and Bumpass, 1989), and of the two-thirds experiencing marital disruption, about threequarters will remarry. Indeed, remarriage has become as common as first marriage-half of all recent marriages involved at least one previously married partner.

These patterns have considerable impact on the nature of family life and the structure of kin networks. Family life for many includes the complexities of stepfamilies (Bumpass, 1984; Cherlin and McCarthy, 1985; Moorman and Hernandez, 1989), including stepparenting, and the absent parent's payment of child support, visiting pat-

Center for Demography and Ecology, 4412 Social Science Building, University of Wisconsin, Madison, WI 53706. terns, and influence in child-related decisions (e.g., Seltzer, 1989). Further, divorce and remarriage alter the extent and character of intergenerational relationships, including grandparenting (Furstenberg, 1981; Hoyert, 1989; Johnson, 1985).

Nonetheless, remarriage receives much less attention in the literature than first marriage. This is probably so because our conceptualization of patterns of marriage, marriage markets, and mateselection processes developed over a period when remarriage was much less common. First marriage is seen as an important marker in the process of becoming an adult, and as representing a major transition in the establishment of an independent household with long-term commitments (and legal obligations) to another person. In contrast, remarriage has often been viewed as simply the restoration of these aspects of adult status after a brief transition period following widowhood or marital disruption.

Discussions of remarriage have usually emphasized that most divorced persons remarry, and have interpreted this as an indication of the strong preference for the married state-even among those whose first marriage was highly unsatisfactory (Spanier and Glick, 1980; Thornton, 1977). This perspective obviously has considerable validity, but we have tended to ignore the theoretical and social importance of variation in remarriage and in the duration after marital dissolution for those who do remarry. When viewed from this perspective, remarriage represents a life course transition very similar in implications to first marriage. Though the definition of "adult" status is not at issue, there is considerable normative ambiguity about the status of previously married persons. At the same time that this status is expected 
to be short-term, there may be some uneasiness among married acquaintances about having a friend who is in the marriage market. For those who do not remarry, marital dissolution represents entry into a lifetime single status. For women, this status is usually associated with markedly reduced economic well-being, especially during the remaining period with children in the household (Garfinkel and McLanahan, 1986). Obviously, similar economic and social support issues are experienced by those in the previously married state for long durations, whether or not they ultimately remarry.

After briefly reviewing recent trends in remarriage rates, the present analysis focuses on the variation in these rates as measured in the 1980 and 1985 June Current Population Surveys. For reasons of data quality, we focus on rates observed in the five years before each of these surveys. We begin by discussing the demographic composition of separation cohorts as a factor affecting remarriage rates and ultimately the structure of remarriages. We next examine proportional-hazard estimates of differentials in remarriage rates. Finally, using life-table procedures, we draw out some of the important implications of differing remarriage rates by estimating expected proportions who will ever remarry.

\section{RECENT TRENDS IN REMARRIAGE}

The figures in Table 1 underscore the importance of the demographic composition of the population at risk of remarriage. The $12 \%$ increase between 1965 and 1984 in the rate per 1,000 previously married persons is an artifact of changing composition with respect to age and widowhood. Because of marked increases in divorce (and some decline in mortality), widows constituted a declining proportion of the population at risk. This resulted in a younger age structure for the total risk population-with the observed consequence of an increase in the total rate of remarriage. In contrast to the observed $12 \%$ increase in this total rate, remarriage rates declined over this period by about $40 \%$ for widows and by about one-third for the divorced.

It is possible that the aging of the widowed population, because of mortality improvements, accounts for some of the decline in their marriage rates. However, it is important to recognize that widowhood is not solely a transition of old age. Though widowhood rates are low during the young and middle ages, effects cumulate over the 40 or so years of exposure between first marriage and retirement age. Our calculations from the June 1985 CPS indicate that a third of all women in 1985 who had ever been widowed were under age 47 when their husband died. Consequently, it is also likely that social and economic factors that affect the remarriage rates of divorced women also are relevant to many widowed women. Nonetheless, because widowhood occurs at disproportionately older ages where remarriage rates are very low, the remainder of this article focuses on remarriage rates of the separated or divorced population.

The rate of remarriage has declined among divorced women of all ages, though the declines were greatest among women under age 25 at the time of divorce $-51 \%$ between 1965 and 1980 . The slight recovery since 1980 may well reflect the changing age structure of divorced women under age 25 , produced by the drop in first-marriage rates of women under age 25 . Increasing cohabitation over the last two decades may also have played some role in declining remarriage rates. In an analysis of measures from the National Survey of Families and Households, we found that the decline in first-marriage rates of young women in the early 1970s was largely offset by the increase in cohabitation (Bumpass and Sweet, 1989b). So also, divorced (and separated) women may have lived in residential unions at a higher rate recently than is suggested by the declines in the remarriage

TABle 1. Remarriage RAtes (PER 1,000/Year) from Vital Statistics

\begin{tabular}{rrrrrrr}
\hline Category & 1965 & 1970 & 1975 & 1980 & 1984 & Percentage Change, 1965-1984 \\
\hline Total & 34 & 37 & 40 & 38 & 38 & $12 \%$ \\
Widowed & 10 & 10 & 8 & 7 & 6 & -40 \\
Divorced & 130 & 123 & 117 & 91 & 87 & -33 \\
$14-24$ & 535 & 413 & 320 & 236 & 260 & -51 \\
$25-44$ & 176 & 180 & 159 & 123 & 130 & -26 \\
$45-64$ & 48 & 43 & 40 & 30 & 31 & -35 \\
\hline
\end{tabular}


rate. Cohabitation creates an ambiguity for the measurement of when a remarriage begins, just as it does for first marriages.

\section{The Current Population Survey Data}

This analysis is based on the marital histories from the June 1980 and June 1985 Current Population Surveys. These data have a clear advantage over vital statistics data because they permit the use of separation instead of divorce dates to identify the timing of marital disruption, and because they allow individual-level analysis of a number of related factors while differences in the duration of risk exposure are held constant. Separation is a more meaningful definition of disruption than divorce because of the dependence of the latter on variations in the legal process and because subgroup variations in the timing and probability of divorce, given separation, can make divorce a very misleading indicator of the timing of marital disruption (Bumpass, Sweet, and Cherlin, 1989; McCarthy, 1978; Sweet and Bumpass, 1974). Except for attempts to replicate vital statistics estimates, the present analysis will condition remarriage on time since separation rather than divorce.

We limit our analysis to the data for women, because of the considerably lower quality of the marriage history data for males (Cherlin and McCarthy, 1983). The variables we can examine are limited by the questions included in the CPS; nonetheless, we can examine differences by race, education, region, age and number of children at separation, age at first marriage, and duration of first marriage.

Vital statistics data provide no information on whether the marked decline in remarriage rates was experienced equally throughout the population. Hence, we had originally hoped to analyze trends for various subgroups. Unfortunately, we concluded that the data were not up to this task. This problem has also been reported by Thornton and Rodgers (1983). The difficulty is simply that we cannot replicate the decline reported in vital statistics when remarriage estimates are compared for either separation or divorce cohorts within the June 1985 CPS. Estimated rates are flat over the period when substantial declines were recorded. Consistent with this, attempts to replicate remarriage rates from the vital statistics for divorced women aged 25-44 do progressively less well for periods more removed from the date of survey. For example, our CPS estimates are 13\% lower than the vital statistics rate for 3 years before survey, but $27 \%$ lower for 13 years before survey.

Because of this difficulty of within-data documentation of trends, we have taken the strategy of focusing on the 1975-79 period with the June 1980 CPS and on 1980-84 with the June 1985 CPS. This focus is not as restrictive as it might seem, since most remarriages occur rather quickly after marital disruption. Even when measured from the date of separation (as opposed to divorce), rates of the early 1980s imply that over half $(57 \%)$ of those who remarry do so within 5 years. (We obtained very similar estimates for our predictor variables using the entire period since 1970.) Further, a trend variable in a pooledhazards analysis of the 1980 and 1985 data estimates a $16 \%$ decline between the two periods, closely replicating the $17 \%$ decline in vital statistics between 1978 and 1983. Since we found that the effects of two of our variables changed over this time period, we have kept the 1980 and 1985 estimates separate for ease of presentation.

\section{CHARACTERISTICS OF RECENT SEPARATION COHORTS}

Remarriage must be seen as embedded in a chain of life-course transitions including first marriage, fertility, marital separation, and divorce. The composition of the population exposed to the risk of remarriage is an outcome of differing birth cohort sizes and characteristics, and subgroup differences in rates of first marriage, fertility, and marital disruption. Populations with higher firstmarriage rates and/or higher rates of marital disruption will be represented more in the population at risk of remarriage. The first two columns in Table 2 report the distribution of first-marriage disruptions in the late 1970 s and early 1980s on the characteristics considered in this analysis.

We tend to think of marital disruption as an event well into the life cycle. However, more than half of recent marital disruptions occurred before age 30 , about a third before age 25 . (There was a slight decline over these two cohorts in the youngest age group, reflecting declines in first-marriage rates of women in their early 20s.) Only $15 \%$ of recent marital disruptions occurred to women over the age of 40 . These age distributions are primarily influenced by the higher disruption rate 
Table 2. Distribution of Recent Separation Cohortsa on Selected Variables and the EFfects of These Variables on RemarRiage Rates

\begin{tabular}{|c|c|c|c|c|c|c|}
\hline \multirow[b]{3}{*}{ Variable } & \multirow{2}{*}{\multicolumn{2}{|c|}{$\begin{array}{l}\text { Percentage } \\
\text { Distribution }\end{array}$}} & \multicolumn{4}{|c|}{ Effects ${ }^{b}$} \\
\hline & & & \multicolumn{2}{|c|}{ Unadjusted } & \multicolumn{2}{|c|}{ Net } \\
\hline & $1975-79$ & $1980-84$ & $1975-79$ & $1980-84$ & $1975-79$ & $1980-84$ \\
\hline $\begin{array}{l}\text { Age at separation } \\
\text { Under } 24 \\
25-29 \\
30-39 \\
40+\end{array}$ & $\begin{array}{l}38 \\
24 \\
23 \\
15\end{array}$ & $\begin{array}{l}31 \\
25 \\
29 \\
15\end{array}$ & $\begin{array}{l}-23 \\
-45 \\
-68\end{array}$ & $\begin{array}{l}-8 c \\
-46 \\
-74\end{array}$ & $\begin{array}{l}-3 c \\
-24 \\
-56\end{array}$ & $\begin{array}{l}-12 c \\
-26 \\
-63\end{array}$ \\
\hline $\begin{array}{l}\text { Education } \\
>12 \text { years } \\
20 \text { years } \\
13+\text { years }\end{array}$ & $\begin{array}{l}24 \\
48 \\
28\end{array}$ & $\begin{array}{l}20 \\
46 \\
33\end{array}$ & $\begin{array}{c}20 \\
-11 \mathrm{c}\end{array}$ & $\begin{array}{l}22 \mathrm{~d} \\
19 \mathrm{~d}\end{array}$ & $\begin{array}{r}9 c \\
-13 c\end{array}$ & $\begin{array}{r}6 \mathrm{c} \\
14 \mathrm{c}\end{array}$ \\
\hline $\begin{array}{l}\text { Race/ethnicity } \\
\text { White } \\
\text { Black } \\
\text { Hispanic }\end{array}$ & $\begin{array}{r}78 \\
13 \\
7\end{array}$ & $\begin{array}{r}76 \\
15 \\
8\end{array}$ & $\begin{array}{l}-76 \\
-30\end{array}$ & $\begin{array}{l}-77 \\
-61\end{array}$ & $\begin{array}{l}-76 \\
-31\end{array}$ & $\begin{array}{l}-73 \\
-55\end{array}$ \\
\hline $\begin{array}{l}\text { Children before se } \\
0 \\
1-2 \\
3+\end{array}$ & $\begin{array}{l}26 \\
49 \\
25\end{array}$ & $\begin{array}{l}29 \\
50 \\
20\end{array}$ & $\begin{array}{l}-18 \\
-50\end{array}$ & $\begin{array}{l}-32 \\
-56\end{array}$ & $\begin{array}{l}-14 d \\
-23\end{array}$ & $\begin{array}{l}-22 \\
-24\end{array}$ \\
\hline $\begin{array}{l}\text { Region } \\
\text { Northeast } \\
\text { North Central } \\
\text { South } \\
\text { West }\end{array}$ & $\begin{array}{l}19 \\
23 \\
37 \\
22\end{array}$ & $\begin{array}{l}17 \\
23 \\
38 \\
2 \Sigma\end{array}$ & $\begin{array}{l}50 \\
71 \\
82\end{array}$ & $\begin{array}{r}99 \\
110 \\
83\end{array}$ & $\begin{array}{l}36 \\
38 \\
42\end{array}$ & $\begin{array}{r}75 \\
103 \\
64\end{array}$ \\
\hline $\begin{array}{l}\text { Age at first marria } \\
\text { Under } 18 \\
18-19 \\
20-22 \\
23+\end{array}$ & $\begin{array}{l}22 \\
32 \\
29 \\
17\end{array}$ & $\begin{array}{l}17 \\
30 \\
29 \\
23\end{array}$ & $\begin{array}{l}-20 \\
-44 \\
-57\end{array}$ & $\begin{array}{l}5^{c} \\
-22 \\
-58\end{array}$ & $\begin{array}{l}-22 \\
-38 \\
-42\end{array}$ & $\begin{array}{l}10^{c} \\
-11^{c} \\
-38\end{array}$ \\
\hline $\begin{array}{l}\text { Duration of first } \mathrm{r} \\
0-1 \\
2-4 \\
5-9 \\
10+\end{array}$ & $\begin{array}{l}17 \\
24 \\
25 \\
35\end{array}$ & $\begin{array}{l}17 \\
23 \\
24 \\
36\end{array}$ & $\begin{array}{l}-20 \\
-25 \\
-54\end{array}$ & $\begin{array}{c}-11 \mathrm{c} \\
-8 \mathrm{c} \\
-47\end{array}$ & & \\
\hline Number of cases & 3,064 & 2,682 & & & & \\
\hline
\end{tabular}

aSeparations 1975-79 from June 1980 Current Population Survey and separations 1980-84 from June 1985 Current Population Survey.

bFrom proportional hazards-model, (Exponent Coefficient $-1 \bullet 100$ ).

Coefficient is less than 1.5 its standard error.

dCoefficient is $1.5-1.9$ its standard error.

of young marriages. We see in the next panel of this table that almost half of the recent first-marriage disruptions were to teenage marriages, onesixth to women under age 18 at first marriage. These distributions have a major impact on the characteristics of remarriages. As we noted in a prior analysis (Castro Martin and Bumpass, 1989), two-thirds of recent remarriages were to women who first married as teenagers, and the average age at remarriage is 33 .

Rates of marital disruption are highest in the early years of marriage, with the result that $40 \%$ of recently separated persons had been married less than 5 years and only one-third had been mar- ried 10 years or more. Nonetheless, this firstmarriage duration is sufficient for most to have borne children, though of course some entered first marriage as mothers, perhaps one of seven (Sweet and Bumpass, 1987). Seventy percent of recently separated women had at least one child before their separation, and one-fifth had three or more. However, there was some increase in childlessness over these two cohorts and some decrease in the proportion with three or more children.

Despite lower first-marriage rates, the higher marital disruption rates of blacks means that they are slightly overrepresented in the separating population. 


\section{DifFERENTIAL RATES OF REMARRIAGE}

The last four columns in Table 2 present differential effects on remarriage rates, estimated from a proportional-hazards model (Menken, Trussell, Stempel, and Babakol, 1981; Teachman, 1982). For continuous variables, the parameter $\beta$ denotes the effect of a unit change in the independent covariate on the log of the hazard rate, with the other independent variables held constant. For categorical covariates, $\beta$ represents the deviation of a specified group from the hazard of the reference group. The exponentials of the coefficients, $\exp (\beta)$, allow us to express the hazard of a specific group as a proportion of the baseline hazard. An $\exp (\beta)$ of 1.0 means that the characteristic analyzed has no effect, whereas an $\exp (\beta)$ of 1.50 , for example, means that marital disruption is $50 \%$ higher than in the comparison category. These effects are expressed as $[\exp (\beta)$ minus 1] 100 and they represent the percentage change in the rate associated with a category of a predictor variable relative to the omitted category.

\section{Age at Separation}

Just as age is a major factor affecting marriage, and age at marriage a major factor affecting marital disruption (Bumpass and Sweet, 1972; Teachman, 1983), age at separation is the most important individual characteristic with respect to remarriage rates. This negative effect, especially strong for women, has been reported in numerous studies (Becker, Landis, and Michael, 1977; Grady, 1980; Koo and Suchindran, 1980; Sweet, 1973; Teachman and Heckert, 1985; Thornton, 1977). The availability of unmarried potential partners within the desirable age range decreases progressively as the person ages, at the same time that age decreases his or her "market position" (Dean and Gurak, 1978). Remarriages are about a quarter lower among women in their $30 \mathrm{~s}$ at separation than among those in their 20 s and are much lower (two-thirds) among women over age 40 .

\section{Duration of First Marriage}

Though closely related to age at separation, duration of first marriage is expected by some to have an independent effect on remarriage behavior. Women whose first marriage lasted relatively long may be more "marriage oriented" and thus remarry sooner (Becker, Landis, and Michael, 1977). Further, they may have invested more in home production skills that are less valuable to them when single, but which can be transferred to a new marriage. In more sociological terms, individuals with long first marriages have had most of their adult experience in married life, and this may influence their capacity to adapt to single life (Sweet, 1973). On the other hand, Koo and colleagues (1984) hypothesize that those women whose first marriages lasted longer may remarry more slowly because they have been outside of the marriage market longer and thus may have fewer relevant skills for finding a new mate.

Though we observe substantially lower remarriage rates for women whose first marriage lasted longer, these effects are completely eliminated when other variables-in particular, age at separation-are controlled. (This result is not shown in Table 2 because we preferred the model controlling age at separation and age at first marriage - and, of course, did not want to include all three measures since each is fully determined by the other two.) Thus it seems that age factors are what matters for remarriage, and not experience or habits associated with first-marriage duration.

\section{Age at First Marriage}

Some of the considerations related to possible effects of first-marriage duration might also be relevant to age at first marriage. For example, the earlier a woman marries, the less experience she can accumulate outside of family life, with the consequence that she may have a lower taste for nonfamily living (Waite, Goldscheider, and Witsberger, 1986). At the same time, early marriers are likely selective of persons with a more traditional family orientation.

In any event, we do find a substantial effect of age at first marriage on remarriage rates: women who married for the first time after age 22 have a $38 \%$ lower remarriage rate, after other variables, including age at separation, are controlled.

\section{Prior Fertility}

Children from previous marriages have traditionally been considered an obstacle to remarriage (Spanier and Glick, 1980). Within Becker's framework (Becker et al., 1977), children are 
"capital" specific to a particular marriage that may deter remarriage by increasing the costs for the potential new partner. These costs include both financial costs and the complexities of a stepfamily. Children may interfere in the courtship process, and they may be reluctant to accept a "surrogate" parent (Sweet, 1973). At the same time, separated women with more children may feel a greater economic need to remarry, which could increase their search effort, and may be less inclined to cohabit.

The empirical evidence is mixed. Becker and associates (1977) and Thornton (1977) found that children reduce the chances of remarriage of their mothers. However, Grady (1980) found no significant effect of the number of children. Koo and Suchindran (1980) found a negative effect of children for younger divorced women and a positive effect for older women (see also Koo, Suchindran, and Griffith, 1984, and Teachman and Heckert, 1985).

We do not find any significant or interpretable interaction between mother's age and the presence of children, nor do we find significant variation by age of youngest child. Women with children are much less likely to remarry than those without, especially those with three or more. Some of this difference is a consequence of the older ages of women with children; however, after mother's age and other variables are controlled, the rate of remarriage is approximately a quarter lower among women with children than among childless women.

\section{Education}

Although higher socioeconomic status is reported as positively associated with the probability of remarriage for men (Wolf and McDonald, 1979), it is inversely associated for women. White (1979) suggests that remarriage tends to select those women less capable of supporting themselves (and their children). Another way of stating this is that, consistent with the "independence" hypothesis often raised in the context of marital disruption, we might expect that women who are more able to support themselves can be more selective in the remarriage market. Hence we might expect an inverse relationship between education and rates of remarriage for women. Further, the higher a woman's education, the more limited is the market supply of more highly educated unmarried men (Goldman, Westoff, and Hammerslough, 1984). On the other hand, it could be argued that education as a resource (for family income as well as more generally) might enhance a woman's market position.

There may well be countervailing forces associated with woman's education, but these data indicate very little association between education and remarriage even before other variables are controlled, and none at all net of these other variables. Despite the lack of a significant effect in either year, we do find, however, that there was a significant interaction between education and year represented in the change from a $13 \%$ lower rate to a $14 \%$ higher rate among college-educated women. Thus it appears that the decline in remarriage rates over this period was experienced least by women who had attended college. That there has been a trend away from a negative education effect is consistent with the contrast between our finding of no effect and the strong negative effect reported for whites by Teachman and Heckert (1985) from the 1973 National Survey of Family Growth.

\section{Race}

Remarriage is much less common among blacks than among whites (Cherlin, 1981; Grady, 1980; Thornton, 1977), and remarriage rates have been declining disproportionately among blacks over the last two decades (Espenshade, 1985). In conjunction with lower rates of first marriage and higher rates of marital disruption and of nonmarital childbearing, this results in a much smaller proportion of the life course being spent in conventional two-parent families among blacks than among whites-with many more years spent in female-headed households both in childhood and for women as adults.

We see in Table 2 that rates of remarriage among blacks are only one-quarter those of white non-Hispanics, and this difference is not at all attributable to compositional differences on the other variables. Hispanics are also less likely to remarry, with rates about half those of white nonHispanics, even after the other variables are controlled. These sharp differences in remarriage rates have marked implications for living arrangements and economic well-being. Since, as noted earlier, blacks are much less likely to divorce after separation than whites, it might be 
thought that these differences in remarriage are compensated for by cohabitation. However, we find that blacks and Hispanics are not more likely than majority whites to cohabit (Bumpass and Sweet, 1989b).

\section{Region}

Finally, we find large regional differences, reflecting primarily the lower rate of remarriage in the Northeast. Rates in the North Central region and the West are over two-thirds higher than those in the Northeast, and remarriage rates in the South are twice as high.

\section{REMARRIAGE DisTRIBUTION AND ESTIMATED PROPORTIONS REMARRYING}

How rapidly does remarriage occur? The answer to this question depends on how the denominator for the calculations is defined. The most commonly available information on this comes from the information collected in vital statistics on time since divorce. For example, a recent report notes: "The interval between marriages in 1983 was 3.6 years for brides and 3.0 years for grooms for all categories of remarriages"' (Wilson, 1989). While technically accurate, such data can be easily misinterpreted to mean that remarriage occurs rather quickly. This is only so, however among those who remarry. It is, in fact, nearly twice as long before half of women experiencing a marital disruption have remarried. We find that recent remarriage rates imply a median duration before remarriage of 7 years, even though we get a figure comparable to the vital statistics figure if we look only at the duration for those who remarried. We also find much subgroup variation in measures not restricted to those who remarried, in contrast to the lack of such variation among remarriages. ${ }^{1}$

Table 3 presents two sets of estimates. The first three columns indicate the quartiles of the distribution of remarriages, based on all separated women. The last column reports the cumulative proportions expected to remarry within 20 years of marital disruption (essentially ever).

These estimates are computed with information from the last separation cohort to complete a given year of duration since separation by 1 June 1985. Thus we observe the risk of remarriage at each duration (conditional on being separated at the start of that duration) for each year between separation and the 20th anniversary. These dura- tion-specific rates are then combined by using lifetable logic to estimate the expected cumulative proportion surviving to specific durations, given recent experience. The quartiles are estimated from the resulting distribution, and the subtraction from $100 \%$ of this expected cumulative survival by 20 years since separation yields the reported expected percentage ever remarrying.

Recent rates imply that $72 \%$ of recently separated women will ultimately remarry (last row, column 4). This is a bit lower than previous estimates, both because of the decline in remarriage rates and because it is based on separation rather divorce. We have previously estimated that about $6 \%$ of separated women will remain separated without ever divorcing (Castro Martin and Bumpass, 1989).

As we would expect from the results we have already seen, the major differences in expected remarriage depend on age at separation and race. The common emphasis in the literature on the average proportion who remarry ignores this variation. While it is the case that almost $90 \%$ remarry among women whose marriages terminate while they are under age 25 , this proportion declines sharply with age to about $60 \%$ for women in their $30 \mathrm{~s}$, and to less than a third for women over age 40 . These differences are sharply reflected in the quartiles of the distribution, with a first quartile of 11 years for women aged 40 and over compared to 4 years for those 30-39; and a median of 12 years for those 30-39 compared to 6 years for those 25-29 at separation.

Although three-quarters of separating white women are likely to remarry, less than half of separating black women are likely to do so. Onequarter remarry in about 3 years among white women, whereas it is about 8 years before onequarter of the black women have remarried. ${ }^{2}$

We saw earlier that differences in remarriage by number of children at separation are partially the result of age differences. They nonetheless characterize an important aspect of the remarriage process as it affects children. About a quarter of separated mothers with one or two children, and two-fifths of those with three or more children, will never remarry. Further, it is 7 years before half of the mothers with one or two children at separation have remarried, and it is almost 14 years for those with three or more children. Even when remarriage occurs, the median time to remarriage is about 5 years. 
TABle 3. Life-Table Estimates of Quartiles of Remarriage Distribution and of Expected Proportion Ever Remarrying after Separation: Experience Centering on 1982

\begin{tabular}{|c|c|c|c|c|}
\hline \multirow[b]{2}{*}{ Variable } & \multicolumn{3}{|c|}{$\begin{array}{c}\text { Quartiles of Remarriage } \\
\text { Distribution (years) of All Women } \\
\text { with Disrupted Marriages } \\
\end{array}$} & \multirow{2}{*}{$\begin{array}{l}\text { Percentage } \\
\text { Remarrying }\end{array}$} \\
\hline & 1 & 2 & 3 & \\
\hline $\begin{array}{l}\text { Age at separation } \\
\text { Under } 25 \\
25-29 \\
30-39 \\
40+\end{array}$ & $\begin{array}{r}2.3 \\
2.8 \\
4.0 \\
11.0\end{array}$ & $\begin{array}{r}4.6 \\
5.8 \\
12.0 \\
-\end{array}$ & $\begin{array}{r}9.7 \\
15.0 \\
- \\
-\end{array}$ & $\begin{array}{l}89 \\
79 \\
59 \\
31\end{array}$ \\
\hline $\begin{array}{l}\text { Duration of first marriag } \\
\qquad-1 \\
2-4 \\
5-9 \\
10+\end{array}$ & $\begin{array}{l}2.3 \\
2.8 \\
3.0 \\
4.2\end{array}$ & $\begin{array}{r}4.4 \\
5.5 \\
6.6 \\
18.0\end{array}$ & $\begin{array}{r}9.3 \\
14.0 \\
18.0 \\
-\end{array}$ & $\begin{array}{l}89 \\
82 \\
76 \\
52\end{array}$ \\
\hline $\begin{array}{l}\text { Age at first marriage } \\
\begin{array}{l}14-17 \\
18-19 \\
20-22 \\
23+\end{array}\end{array}$ & $\begin{array}{l}2.6 \\
2.6 \\
3.2 \\
4.4\end{array}$ & $\begin{array}{r}5.0 \\
5.8 \\
8.0 \\
16.0\end{array}$ & $\begin{array}{r}11.7 \\
17.0 \\
- \\
-\end{array}$ & $\begin{array}{l}84 \\
79 \\
67 \\
51\end{array}$ \\
\hline $\begin{array}{l}\text { Children at separation } \\
0 \\
1-2 \\
3+\end{array}$ & $\begin{array}{l}2.5 \\
3.2 \\
4.2\end{array}$ & $\begin{array}{r}4.7 \\
7.0 \\
13.7\end{array}$ & $\frac{12.0}{-}$ & $\begin{array}{l}81 \\
73 \\
57\end{array}$ \\
\hline $\begin{array}{l}\text { Race } \\
\text { White non-Hispanic } \\
\text { Black }\end{array}$ & $\begin{array}{l}2.8 \\
8.2\end{array}$ & $\frac{6.0}{-}$ & $\stackrel{18.0}{-}$ & $\begin{array}{l}76 \\
46\end{array}$ \\
\hline $\begin{array}{l}\text { Education } \\
0-11 \text { years } \\
12 \text { years } \\
13+\end{array}$ & $\begin{array}{l}3.1 \\
2.9 \\
3.2\end{array}$ & $\begin{array}{l}8.5 \\
6.4 \\
7.4\end{array}$ & $\begin{array}{c}- \\
20.0 \\
-\end{array}$ & $\begin{array}{l}67 \\
75 \\
72\end{array}$ \\
\hline $\begin{array}{l}\text { Region } \\
\text { Northeast } \\
\text { North Central } \\
\text { South } \\
\text { West }\end{array}$ & $\begin{array}{l}4.5 \\
2.7 \\
2.7 \\
3.4\end{array}$ & $\begin{array}{r}10.0 \\
7.0 \\
5.8 \\
7.2\end{array}$ & $\begin{array}{r}- \\
17.0 \\
18.0\end{array}$ & $\begin{array}{l}60 \\
70 \\
77 \\
78\end{array}$ \\
\hline Total & 3.0 & 7.0 & - & 72 \\
\hline
\end{tabular}

\section{CONCLUSION}

In the context of high levels of marital disruption, remarriage has become a very common aspect of American family experience. Whether or not remarriage occurs after disruption has important implications for economic and social well-being. While the majority of disruptions are followed by remarriage, there are very important variations in how long remarriage is delayed and in whether it occurs at all.

Because of data limitations, this analysis has been restricted to patterns among women. It would obviously be preferable to also be able to analyze patterns for men. Men are more likely to remarry than women, but those who do not, seem to suffer greater social isolation and ill health. At the same time, the implications of remarriage are particularly profound for women in two related respects. Most obvious is the growth in motheronly families and the marked poverty experience of such families.

From the point of view of the children involved, we recently estimated that the majority of children entering single-parent families will live out their childhood without ever entering a second family (Bumpass and Sweet, 1989a). Even when children are not present in the disrupting marriage, or when they have grown up and left home, remaining unmarried is associated with markedly lower economic well-being.

Remarriage rates vary greatly, depending particularly on age at disruption and race, but also on whether children are present. The present analysis was able to take advantage of the relatively large samples of the Current Population Survey but was limited by the variables available in the survey. 
Because remarriage is now such a basic aspect of our family experience, it is critical that we devote much more attention to the determinants and consequences of varying durations in the separated or divorced state, as well as to how the remarriages may differ from first marriages.

\section{NoTES}

1. The focus on those who remarried in vital statistics is understandable because denominators are not readily available for the more appropriate measure. The duration since divorce for remarriage cohorts tells us something potentially important about the experience brought to remarriages but is moot with respect to levels and variations in the pace of remarriage after disruption. This is just an instance of the problem of "truncation by interview" for which life table and hazard procedures are commonly employed.

2. When based only on women who remarried, the differences by both age at separation and by race disappear.

\section{REFERENCES}

Becker, Gary S., Michael Landis, and Robert Michael. 1977. "An economic analysis of marital instability." Journal of Political Economy 85: 1141-1187.

Bumpass, Larry L. 1984. "Demographic aspects of children's second-family experience." American Journal of Sociology 90(3): 608-623.

Bumpass, Larry L., and James A. Sweet. 1972. "Differentials in marital instability." American Sociological Review 37: 71-82.

Bumpass, Larry L., and James A. Sweet. 1989a. "Children's experience in single-parent families: Implications of cohabitation and marital transitions." Family Planning Perspectives 21(6): 256-260.

Bumpass, Larry L., and James A. Sweet. 1989b. "National estimates of cohabitation: Cohort levels and union stability." Demography 26: 615-625.

Bumpass, Larry L., James A. Sweet, and Andrew Cherlin. 1989. "The role of cohabitation in declining rates of marriage." NSFH Working Paper 5, Center for Demography and Ecology, University of Wisconsin-Madison.

Castro Martin, Teresa, and Larry L. Bumpass. 1989. "Recent trends and differentials in marital disruption." Demography 26: 37-51.

Cherlin, Andrew. 1981. Marriage, Divorce, Remarriage. Cambridge, MA: Harvard University Press.

Cherlin, Andrew, and James McCarthy. 1983. "A note on maritally-disrupted men's reports of child support in the June 1980 Current Population Survey." Demography 20: 385-389.

Cherlin, Andrew, and James McCarthy. 1985. "Remarried couples households: Data from the June 1980 Current Population Survey." Journal of Marriage and the Family 47: 23-30.
Dean, Gillian, and Douglas T. Gurak. 1978. "Marital homogamy the second time around." Journal of Marriage and the Family 40: 559-570.

Espenshade, Thomas J. 1985. "Marriage trends in America: Estimates, implications, and underlying causes." Population and Development Review 11: 193-245.

Furstenberg, Frank. 1981. "Remarriage and intergenerational relations.” Pp. 117-142 in R. Fogel, E. Hatfield, S. Kiesler, and J. March (eds.), Aging: Stability and Change in the Family. New York: Academic Press.

Garfinkel, Irwin, and Sara McLanahan. 1986. Female Headed Families and Public Policy: A New American Dilemma? Washington, DC: Urban Institute.

Goldman, Noreen, Charles F. Westoff, and Charles Hammerslough. 1984. "Demography of the marriage market in the United States." Population Index 50: 5-25.

Grady, William R. 1980. Remarriages of Women 15-44 Years of Age Whose First Marriage Ended in Divorce: United States, 1976. Advance Data, National Center for Health Statistics 58. Washington, DC: U.S. Department of Health and Human Services.

Hoyert, Donna L. 1989. "Intergenerational exchange of financial and household assistance." Unpublished master's thesis, University of Wisconsin-Madison.

Johnson, Coleen L. 1985. "Grandparenting options in divorcing families: An anthropological perspective." Pp. 81-96 in V. Bengtson and J. Robertson (eds.), Grandparenthood. Beverly Hills, CA: Sage Publications.

Koo, Helen, and C. Suchindran. 1980. "Effects of children on women's remarriage prospects." Journal of Family Issues 1: 497-515.

Koo, Helen, C. Suchindran, and Janet D. Griffith. 1984. "The effects of children on divorce and remarriage: A multivariate analysis of life table probabilities." Population Studies 38: 451-472.

McCarthy, James. 1978. "A comparison of the probability of the dissolution of first and second marriages." Demography 20: 2-19.

Menken, J., J. Trussell, D. Stempel, and O. Babakol. 1981. "Proportional hazards life table models: An illustrative analysis of socio-demographic influences on marriage dissolution in the U.S." Demography 18: 181-200.

Moorman, Jeanne E., and Donald J. Hernandez. 1989. "Married-couple families with step, adopted, and biological children." Demography 26: 267-278.

Seltzer, Judith. 1989. "Relationships between fathers and children who live apart." NSFH Working Paper 4, Center for Demography and Ecology, University of Wisconsin-Madison.

Spanier, Graham, and Paul Glick. 1980. "The life cycle of American families: An expanded analysis." Journal of Divorce 3: 283-298.

Sweet, James A. 1973. "Differentials in remarriage probabilities." CDE Working Paper 73-29, Center for Demography and Ecology, University of Wisconsin-Madison. 
Sweet, James A., and Larry Bumpass. 1974. "Differentials in marital instability in the black population: 1970." Phylon 35: 323-331.

Sweet, James A., and Larry L. Bumpass. 1987. American Families and Households. New York: Russell Sage Foundation.

Teachman, Jay. 1982. "Methodological issues in the analysis of family formation dissolution." Journal of Marriage and the Family 44: 613-621.

Teachman, Jay. 1983. "Early marriage, premarital fertility, and marital dissolution: Results for blacks and whites."' Journal of Family Issues 4: 105-126.

Teachman, Jay, and Alex Heckert. 1985. "The impact of age and children on remarriage: Further evidence." Journal of Family Issues 6: 185-203.

Thornton, Arland. 1977. "Decomposing the remarriage process." Population Studies 31: 383-392.

Thornton, Arland, and Willard Rodgers. 1983. "Changing patterns of marriage and divorce in the United States." Final Report, Contract NO1HD-02850, National Institute for Child Health and Human Development.

Waite, Linda J., Frances K. Goldscheider, and Christina Witsberger. 1986. "Nonfamily living and the erosion of traditional family orientations among young adults." American Sociological Review 51: 541-554.

White, Lynn K. 1979. "Sex differentials in the effect of remarriage on global happiness." Journal of Marriage and the Family 41: 869-876.

Wilson, B. F. 1989. Remarriages and Subsequent Divorces: United States. Vital and Health Statistics, Series 21, No. 45. DHHS Publication No. (PHS) 89-1923, Public Health Service. Washington, DC: U.S. Government Printing Office.

Wolf, Wendy C., and Maurice MacDonald. 1979. "The earnings of men and remarriage." Demography 16: 389-400. 